\title{
Southern rice black-streaked dwarf virus (SRBSDV) directly affects the feeding and reproduction behavior of its vector, Sogatella furcifera (Horváth) (Hemiptera: Delphacidae)
}

Hongxing $\mathrm{Xu}^{1+}$, Xiaochan $\mathrm{He}^{2+}$, Xusong Zheng ${ }^{1}$, Yajun Yang ${ }^{1}$, Junce Tian ${ }^{1}$ and Zhongxian $\mathrm{Lu}^{1 *}$

\begin{abstract}
Background: Southern rice black-streaked dwarf virus (SRBSDV) is a recently discovered member of the genus Fijivirus and it is transmitted by the rice whitebacked planthopper (WBPH), Sogatella furcifera (Horváth). It was found that SRBSDV infected vectors might contribute negatively to the WBPH population, although the longer nymphal period might benefit viral acquisition, transmission and increase infection rate. The interaction between SRBSDV and its vector need to be further explored to gain better understanding of the dispersal of WBPH and the spread of virus disease, in particular the feeding and reproduction behavior of viruliferous WBPH.

Methods: Newly hatched nymphs of WBPH were fed on healthy rice plant after feeding on SRBSDV-infected rice plants for $2 \mathrm{~h}$, and newly emerged adults were numbered and tested. Feeding behaviors of WBPH adults were monitored electronically within a Faraday cage using a Giga-4 DC EPG amplifier. The newly emerged adults were paired, and the fecundity and egg hatchability were investigated. WBPH was molecularly identified for SRBSDV when they dead. According to the identification results, data on viruliferous and non-viruliferous WBPH were collected and analyzed.
\end{abstract}

Results: Feeding behavior of viruliferous WBPH was different from those of non-viruliferous WBPH. Frequency of phloem sap ingestion of viruliferous WBPH increased significantly, however the total feeding duration did not increase markedly. When both WBPH parents were infected with SRBSDV, their fecundity and hatchability of the eggs produced were significant lower than those of normal WBPH parents. However, if only one of the parents was viruliferous, fecundity and egg hatchability were only slightly affected.

Conclusions: Viruliferous WBPH fed on the phloem more frequently than non-viruliferous WBPH and can thus contribute to virus transmission. When both vector parents are viruliferous fecundity and hatchability of the eggs were significantly reduced. However when only one of the parents WBPH was viruliferous, there were no significant effects.

Keywords: Southern rice black-streaked dwarf virus (SRBSDV), Whitebacked planthopper (WBPH), Sogatella furcifera, Feeding behavior, Reproduction

\footnotetext{
* Correspondence: luzxmh@gmail.com

${ }^{\dagger}$ Equal contributors

'State Key Laboratory Breeding Base for Zhejiang Sustainable Pest and Disease Control, Institute of Plant Protection and Microbiology, Zhejiang Academy of Agriculture Sciences, Add. No 198 Shiqiao Rd, Hangzhou 310021, P R China

Full list of author information is available at the end of the article
}

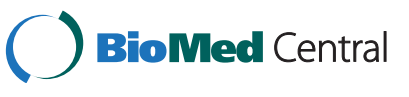

(c) 2014 Xu et al.; licensee BioMed Central Ltd. This is an Open Access article distributed under the terms of the Creative Commons Attribution License (http://creativecommons.org/licenses/by/2.0), which permits unrestricted use, distribution, and reproduction in any medium, provided the original work is properly credited. The Creative Commons Public Domain Dedication waiver (http://creativecommons.org/publicdomain/zero/1.0/) applies to the data made available in this article, unless otherwise stated. 
Southern rice black-streaked dwarf virus (SRBSDV) transmitted by the whitebacked planthopper (WBPH), Sogatella furcifera (Horváth), is a recently identified member of the genus Fijivirus in the family Reoviridae. The virus disease has caused disastrous damages in rice and maize production in China [1,2]. It was also recently recorded in Vietnam [3,4] and Japan [5]. In 2010, more than 60,000 ha of paddy fields in 29 provinces of Vietnam and more than 1,300,000 ha in 13 provinces of China were infected $[3,4,6]$ while in 2011 the SRBSDV damaged more than 700,000 ha and in 2012 over 500,000 ha in China and Vietnam [7]. The losses in rice production can threaten food safety in these areas [3,7].

Since it was discovered, some studies had been conducted. Pu et al. (2012) showed that the frequency of viruliferous WBPH increased with the longer access time after $24 \mathrm{~h}$ virus feeding [8]. Viruliferous WBPH with SRBSDV feeding on viruliferous rice plant showed significant changes in fitness, including prolonged nymphal stages and reduced survival rates. Viruliferous rice plants also affected non-viruliferous WBPH by extending their survival rates at the temperature of $20^{\circ} \mathrm{C}$ and lowering their survival rates at a higher temperature of $28^{\circ} \mathrm{C}$. Furthermore, both viruliferous WBPH and non-viruliferous WBPH populations had significantly shorter adult life spans at $25^{\circ} \mathrm{C}$ and lower fecundity at $28^{\circ} \mathrm{C}$ relative to the control [9]. In general, both SRBSDV infected vectors and host plants were unfavorable to WBPH population growth but longer nymphal periods [10]. A longer nymphal period might benefit viral acquisition and transmission by nymphs and might increase local infection rates [9]. Interactions between SRBSDV and its vector need to be further explored to better understand the dispersal of WBPH and the spread of virus.

There are generally different effects of viruses on the biology of vector insect [11,12]. Ecological fitness and feeding behavior of vectors may also be affected $[13,14]$. However, the differences in how the virus might affect the feeding and reproduction of viruliferous and nonviruliferous WBPH have not been explored.

In this paper we report studies on the feeding behavior of viruliferous and non-viruliferous WBPH. In addition we also assessed the effects on the reproduction charactersistics of WBPH when both or one of the parents infected with SRBSDV. The results would help to further understand the relationship between SRBSDV and its vector to improve the management of $\mathrm{WBPH}$ and the SRBSDV disease.

\section{Results}

\section{EPG waveforms of WBPH}

The EPG waveforms recorded from viruliferous and non-viruliferous WBPH were similar. There were seven distinctive waveforms, non-penetration (np), penetration initiation (N1), salivation and stylet movement (N2), extracellular activity near the phloem region (N3), pathway phase $(\mathrm{NC})$, intracellular activity in the phloem tissue (N4a), phloem sap ingestion (N4b), stylets in the phloem tissue (N4) (including N4-a and N4-b), and stylets in the xylem tissue (N5) (Figure 1).

The parameters of EPG waveforms recorded from viruliferous and non-viruliferous WBPH are shown in Table 1. Duration of non-penetration of stylets, total durations of N4-a and N5 waveforms of viruliferous WBPH were prolonged, and the numbers of occurrences of N1, N2, N3, N4 and N5 waveforms were also higher than those of non-viruliferous WBPH. However, the differences were not significant. The number of N4-b waveform occurrence in the viruliferous WBPH was obviously higher, and the average and total duration of N4-b waveform were shorter than those of non-viruliferous WBPH. This indicated that viruliferous WBPH fed in phloem more frequently than the non-viruliferous WBPH. On the other hand the frequency and duration of xylem sap ingestion (N5 waveform) of viruliferous WBPH fed in phloem were slightly higher and longer than those of non-viruliferous WBPH.

\section{Effects of SRBSDV on fecundity and egg hatchability of WBPH}

Compared to control $\left(q_{(-)} \times \hat{O}_{(-)}\right)$, the fecundity of viruliferous pairs of male and females were significantly decreased by $76.25 \%$. The hatchability of eggs from these pairs was also reduced by $30.72 \%$. When only one of the pairs was viruliferous fecundity and egg hatchability were slightly affected and not significantly different from the control (Table 2).

\section{Discussion}

Feeding behavior of the viruliferous vector may be altered by the plant virus. For instance the virus particles of Maize streak virus (MSV) were found in cells of phloem parenchyma, vascular bundle sheath and mesophyll tissue, and also in epidermal guard cells of plants infected with the maize strain of MSV. When the vector leafhopper Cicadulina mbila fed on MSV-infected plants, its feeding preferences was altered and the duration of feeding in mesophyll cell was prolonged. On healthy plants they primarily fed on the phloem. The feeding behavior changes benefited MSV by improving the acquisition and transmission efficiency of the vector [15]. Feeding behavior of vector beet leafhopper, Circulifer tenellus (Baker), was also found to be related with the transmission of Beet severe curly top virus (BSCTV). Waveform D1, which was associated with phloem salivation, was the only waveform correlated with inoculation of BSCTV [16]. Our results showed that the number of occurrence of N4-b waveform of viruliferous 


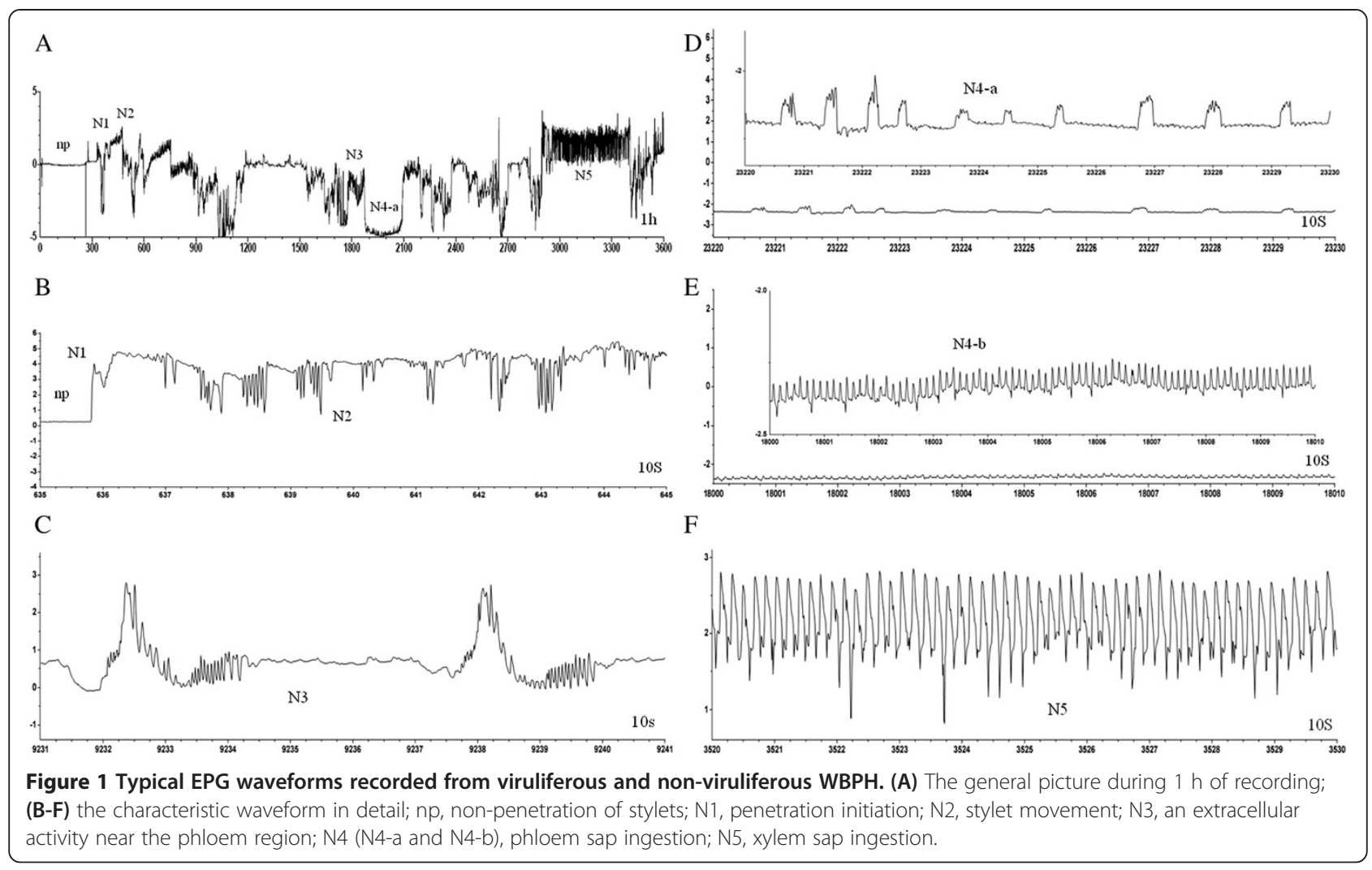

WBPH was obviously higher than that of nonviruliferous WBPH, and the average duration of N4-b waveform was shorter than that of non-viruliferous WBPH. It indicated that viruliferous WBPH fed in phloem more frequently than non-viruliferous WBPH and thus may benefit the spread of SRBSDV. It was also reported that both the viruliferous and nonviruliferous WBPH or Rice ragged stunt virus (RRSV)carrying $\mathrm{BPH}$ preferred healthy plants to infected plants which might mean that plant viruses may alter host selection preference of vectors to enhance their spread and that of insects vectoring another virus to result in co-infection with more than one virus [10]. However, the specific stylet penetration behavior associated with inoculation of SRBSDV needs further investigation.

Our earlier studies showed that the fitness of viruliferous WBPH was affected. The nymphal duration of the male was prolonged markedly, the weight and fecundity of the female decreased significantly and the average survival time was shortened at both test temeperatures of $26^{\circ} \mathrm{C}$ and $31^{\circ} \mathrm{C}$ (Xu et al., unpublished data). It was reported that the viruliferous WBPH laid significant less eggs than non-viruliferous hoppers. There were no significant differences in the hatchability of eggs laid by virulifierous and non viruliferous females [9]. This study using paired viruliferous and nonviruliferous WBPH showed that both infected females and males had significantly reduced fecundity and the F1 egg hatchability. When paired with either a non viruliferous female or male, there were no significant effects in fecundity and egg hatchability. One may speculate that the genes involved in primary metabolism, ubiquitin-proteasome, cytoskeleton dynamics and immune responses were up regulated in viruliferous WBPH [17]. Since WBPH adult has active mobility and frequently move among rice plants, it is likely that pairing with only one viruliferous adult is more common and thus might not reduce WBPH populations. One viruliferous WBPH could transmit virus to 15 to 17 rice plants in five days or about 49 plants during its whole lifespan $[8,18]$, and thus virus spread will probably be retained or increased [19].

Viriliferous vectors have reduced fecundities [20,21]. Tomato yellow leaf curl virus (TYLCV) infested vectors Bemisia tabaci (Genadius) also have about for 17-23\% shorter longevity and reduced fecundity of about 40-50\% [22]. Similarly in western flower thrips (WFT), Frankliniella occidentalis (Pergande), exposed to Tomato spotted wilt virus (TSWV) compared to the unexposed thrips reared on uninfected leaf discs, mean daily fecundity was reduced and the egg hatchability affected as well [23]. Parents of small brown planthopper (SBPH), Laodelphax striatellus (Fallen), especially the male, infected with Rice striped virus (RSV) also had significant effects on the egg hatchability of the next generation [24]. On the other hand some 
Table 1 Parameters of EPG waveforms of female WBPH adult

\begin{tabular}{|c|c|c|c|}
\hline Parameters & Non-viruliferous & Viruliferous & $P$ \\
\hline Number of occurrences of $n p$ & $15.50 \pm 2.23$ & $24.13 \pm 6.08$ & 0.216 \\
\hline Average duration of $\mathrm{np}$ (min) & $3.50 \pm 0.51$ & $4.07 \pm 1.09$ & 0.609 \\
\hline Total duration of np (min) & $57.00 \pm 11.54$ & $75.80 \pm 18.76$ & 0.377 \\
\hline Number of occurrences of $\mathrm{N} 1$ & $15.42 \pm 2.22$ & $24.13 \pm 6.08$ & 0.212 \\
\hline Number of occurrences of N2 & $34.33 \pm 4.66$ & $40.00 \pm 10.60$ & 0.636 \\
\hline Number of occurrences of N3 & $7.92 \pm 1.69$ & $12.50 \pm 6.41$ & 0.421 \\
\hline Average duration of Nc (min) & $4.80 \pm 2.18$ & $3.66 \pm 0.80$ & 0.686 \\
\hline Total duration of Nc (min) & $105.62 \pm 23.06$ & $130.16 \pm 33.99$ & 0.542 \\
\hline Number of occurrences of N4-a & $2.75 \pm 1.00$ & $4.25 \pm 1.42$ & 0.386 \\
\hline Average duration of N4-a (min) & $5.37 \pm 1.30$ & $4.41 \pm 2.31$ & 0.699 \\
\hline Total duration of N4-a (min) & $14.86 \pm 4.00$ & $23.84 \pm 13.88$ & 0.472 \\
\hline Number of occurrences of N4-b & $0.83 \pm 0.21$ & $1.75 \pm 0.37$ & 0.030 \\
\hline Average duration of N4-b (min) & $113.44 \pm 29.41$ & $53.99 \pm 27.40$ & 0.179 \\
\hline Total duration of N4-b (min) & $126.71 \pm 29.38$ & $82.71 \pm 32.37$ & 0.338 \\
\hline Number of occurrences of $\mathrm{N} 4$ & $2.75 \pm 1.00$ & $4.63 \pm 1.40$ & 0.277 \\
\hline Total duration of N4 (min) & $141.57 \pm 31.27$ & $106.55 \pm 33.39$ & 0.467 \\
\hline Number of occurrences of N5 & $13.92 \pm 3.99$ & $16.00 \pm 5.89$ & 0.764 \\
\hline Average duration of N5 (min) & $6.91 \pm 1.58$ & $15.14 \pm 5.61$ & 0.195 \\
\hline Total duration of N5 (min) & $55.46 \pm 11.73$ & $96.31 \pm 28.00$ & 0.145 \\
\hline Percentage of $\mathrm{Nc}(\mathrm{N} 2+\mathrm{N} 3)$ in the whole recording time & $15.83 \pm 3.21$ & $21.06 \pm 5.21$ & 0.418 \\
\hline Percentage of $\mathrm{np}$ in the whole recording time & $29.34 \pm 6.40$ & $36.16 \pm 9.44$ & 0.550 \\
\hline Percentage of $\mathrm{N} 5$ in the whole recording time & $15.41 \pm 3.26$ & $26.75 \pm 7.78$ & 0.111 \\
\hline Percentage of $\mathrm{N} 4$ in the whole recording time & $39.32 \pm 8.69$ & $29.60 \pm 9.27$ & 0.577 \\
\hline Percentage of N4-a in the whole recording time & $4.13 \pm 1.11$ & $6.62 \pm 3.86$ & 0.739 \\
\hline Percentage of N4-b in the whole recording time & $35.20 \pm 8.16$ & $22.98 \pm 8.99$ & 0.492 \\
\hline
\end{tabular}

Note: $\mathrm{Nc}=\mathrm{N} 2+\mathrm{N} 3 ; \mathrm{N} 4=\mathrm{N} 4 \mathrm{a}+\mathrm{N} 4 \mathrm{~b}$. Data were means \pm SE.

researchers have found that the total number of oocytes and the proportion of oocytes developed at the grade I status in the vector green leafhopper, Nephotettix cincticeps (Uhler), were significantly increased when they were fed on Rice dwarf virus (RDV)-infected rice plants [25].

Furthermore, Co-infection of the begomovirus Tomato yellow leaf curl China virus (TYLCCNV) and its betasatellite can repress a-regulated defences of tobacco against invasive whiteflies Bemisia tabaci (Gennadius) and

Table 2 Effects of SRBSDV on the fecundity, and egg hatchability of WBPH

\begin{tabular}{cccc}
\hline Combination & Number & Eggs laid/ ${ }_{+}$ & Hatchability (\%) \\
\hline$q_{(+)} \times \widehat{O}_{(-)}$ & 15 & $56.33 \pm 8.19 \mathrm{ab}$ & $94.35 \pm 0.04 \mathrm{a}$ \\
$q_{(-)} \times \widehat{O}_{(+)}$ & 18 & $59.25 \pm 15.73 \mathrm{ab}$ & $93.53 \pm 0.03 \mathrm{a}$ \\
$q_{(+)} \times \widehat{O}_{(+)}$ & 10 & $16.50 \pm 4.03 \mathrm{~b}$ & $66.67 \pm 0.21 \mathrm{~b}$ \\
$q_{(-)} \times \widehat{\partial}_{(-)}($control) & 30 & $69.47 \pm 6.88 \mathrm{a}$ & $96.23 \pm 0.02 \mathrm{a}$ \\
\hline
\end{tabular}

Note: $\rho_{(+)}$and $\hat{O}_{(+)}$are female and male of WBPH infected with SRBSDV; $q_{(-)}$ and $\hat{\sigma}_{(-)}$are female and male of WBPH uninfected with SRBSDV, respectively. Data were means \pm SE. The data in the same column followed by different letters indicated the significant difference $(P<0.05)$. accelerate population increases of the insects [26]. The tripartite interactions of plant-pathogen-vector relationships are complex. And these results provide an interesting model to study the plant-pathogen-vector interactions through an integration of ecological, physiological and molecular approaches.

\section{Conclusions}

Our results showed viruliferous WBPH fed on phloem more frequently than non-viruliferous WBPH which might increase the probability of virus transmission. When only female or male WBPH was infected with SRBSDV, the fecundity and egg hatchability were lower than those of the non-infected pairs although not significant. If however both sexes were viruliferous, the fecundity and egg hatchability were adversely affected.

\section{Materials and methods}

Rice plants

Rice variety Y-liangyoul was used in the experiment. It is a dominant indica hybrid rice in Wuyi county 
$\left(119.81^{\circ} \mathrm{E}, 28.9^{\circ} \mathrm{N}\right)$, Zhejiang province, China, where the SRBSDV disease frequently outbreaks. Germinated rice seeds were sown at the rate of $15 \mathrm{~kg}$ per hectare and transplanted at one seedling per hill spaced 20 by $20 \mathrm{~cm}$ apart. A total of $90 \mathrm{~kg} \mathrm{~N}, 90 \mathrm{~kg} \mathrm{P}$ and $144 \mathrm{~kg}$ K per hectare was applied as base fertilizer before planting. Another $90 \mathrm{~kg} \mathrm{~N}$ was applied in two splits at tillering stage $(60 \%)$ and reproductive stage (40\%). Rice was naturally infected by immigrant viruliferous WBPH. Thirty days after sowing, rice plants with visible SRBSDV-infected symptoms were marked. The healthy and infected rice plants with typical disease symptoms were uprooted and transplanted individually in clay pots $(\Phi=15 \mathrm{~cm})$. After all arthropods were manually eliminated, potted plants were covered with a cage made of a transparent plastic cylinder with nylon mesh at the top for ventilation. All plants were molecularly identified following the method of Li et al. (2012) [27].

\section{WBPH}

A strain of WBPH were collected in experimental farm of China National Rice Research Institute in Hangzhou $\left(119.95^{\circ} \mathrm{E}, 30.07^{\circ} \mathrm{N}\right)$, China and maintained on healthy rice plants in laboratory. Fifty 5 th instar nymphs of 2 nd generation were collected and reared individually. After emergence, male and female WBPH were paired and transferred to a caged rice plant for oviposition. Adults were identified by RT-PCR to confirm whether they were viruliferous or not after they were died. All offspring of virus-free of original insects were maintained on healthy rice plants at $26 \pm 1^{\circ} \mathrm{C}$ with photoperiods of 12 L: 12D. Newly hatched nymphs of next generation were used in this study.

Acquisition of viruliferous and non-viruliferous WBPH adults Following the methods described by $\mathrm{He}$ et al. (2011) [28], 45-day-old healthy or SRBSDV-infected rice plants were removed outer sheaths and inactive roots and cleaned carefully with tap water and were placed in a glass tube (diameter $2.5 \mathrm{~cm}$, height $18 \mathrm{~cm}$ ) with $1.5 \mathrm{~cm}$ deep Kimura B nutrient solution individually. Ten newly hatched nymphs of WBPH were introduced into a glass tube with healthy rice plant after feeding on SRBSDVinfected rice plants for $2 \mathrm{~h}$. All the glass tubes were kept in a climate chamber with $26 \pm 1^{\circ} \mathrm{C}$, relative humidity (RH) of $75-90 \%$ and photoperiods of $12 \mathrm{~L}: 12 \mathrm{D}$. Rice plants were replaced and Kimura B nutrient solution was replenished if needed. When adults emerged, they were used in the following experiments.

\section{Effect of SRBSDV on feeding behaviors of WBPH adults}

Following the methods described by $\mathrm{He}$ et al. (2011) [29], feeding behavior of WBPH adults were monitored electronically within a Faraday cage using a Giga-4 DC
EPG amplifier with a $10^{9} \Omega$ input resistance and an input bias current of less than $1 \mathrm{pA}$ (Wageningen Agricultural University, The Netherlands). Female adults, which emerged within $8 \mathrm{~h}$ were transferred into a glass tube (diameter $2 \mathrm{~cm}$, length $10 \mathrm{~cm}$ ) and provided water only (water-saturated cotton) for two hours before used. One end of a gold wire (diameter $20 \mu \mathrm{m}$, length $10 \mathrm{~cm}$ ) was attached to the dorsal thorax of WBPH with watersoluble silver conductive glue. The other end of the wire was connected to the amplifier through the EPG probe. A copper wire (diameter $2 \mathrm{~mm}$, length $10 \mathrm{~cm}$ ) was inserted into the soil to serve as the plant electrode. The female attached to the gold wire was carefully placed onto the stem of healthy rice plant. The gain of the amplifier was set at $50 \times$, and the plant voltage was adjusted to obtain an output voltage of between -5 and $+5 \mathrm{~V}$. EPG signals were analyzed with the PROBE 3.0 software (Wageningen Agricultural University, The Netherlands). After EPG recording for $6 \mathrm{~h}$, the females were identified for SRBSDV individually. According to the identification results, 22 and 18 replications were applied for viruliferous WBPH and non-viruliferous WBPH, respectively. All the EPG tests were conducted at $26 \pm 1^{\circ} \mathrm{C}, 70 \pm 5 \% \mathrm{RH}$ and continuous light conditions.

EPG waveforms from WBPH recorded in the tests were characterized using the correlations found in Seo et al. (2009) [30] and He et al. (2011) [29]. Seven distinctive waveforms were classified and analyzed with a modified method as Sarria et al. (2009) described [31]. Four parameters of non-sequential variables of each EPG waveform, including total duration, average duration, number of occurrences and proportion of each waveform phase in whole recording time were analyzed.

\section{Effects of SRBSDV on reproduction of WBPH}

Newly emerged adults were paired and transferred into a glass tube with two healthy rice tillers. They were allowed to mate and oviposit until death, and the fecundity was investigated as described below. Each tube was observed daily and newly hatched nymphs were counted and removed every day until no more nymphs hatched. Unhatched eggs were counted by dissecting under microscope. Death WBPH adults were collected and molecularly identified individually to confirm if they were infected with SRBSDV. According to the identification results, 15, 18, 10 and 30 replications were applied for the treatments viruliferous female $q_{(+)} \times$non-viruliferous male $\hat{\sigma}_{(-)}$, non-viruliferous female $\phi_{(-)} \times$viruliferous male $\hat{\partial}_{(+)}$, $\hat{q}_{(+)} \times \hat{o}_{(+)}$and $\hat{q}_{(-)} \times \hat{\sigma}_{(-)}$, respectively.

\section{Statistical analysis}

The data on feeding behavior of viruliferous and nonviruliferous WBPH were analyzed using student's $t$-test. Single factor analysis of variance was conducted to 
analyze the fecundity and egg hatchability of WBPH (egg hatchability were transformed into arcsine and square root values, respectively before performing the statistical analyses). All statistical tests were performed using SPSS V18.0.

\section{Competing interests}

The authors declare that they have no competing interests.

\section{Authors' contributions}

$\mathrm{HX}$ and $\mathrm{XH}$ carried out the experiments and drafted the manuscript. XZ was involved in collecting WBPH and SRBSDV-infected rice plants. YY and JT helped with experimental procedures and manuscript preparation. $\mathrm{ZL}$ designed the study and critically revised the manuscript. All authors read and approved the final manuscript.

\section{Acknowledgements}

This study was supported by the National Basic Research Program of China (973, Grant No. 2010CB126202), the Agro-Industry R \& D Special Fund of China (Grant No. 201003031). We are grateful to Dr. K. L. Heong for the revision of the manuscript.

\section{Author details}

${ }^{1}$ State Key Laboratory Breeding Base for Zhejiang Sustainable Pest and Disease Control, Institute of Plant Protection and Microbiology, Zhejiang Academy of Agriculture Sciences, Add. No 198 Shiqiao Rd, Hangzhou 310021 , P R China. ${ }^{2}$ Jinhua Academy of Agricultural Sciences, Jinhua 321017, $P R$ China.

Received: 5 November 2013 Accepted: 19 March 2014 Published: 24 March 2014

\section{References}

1. Zhang HM, Yang J, Chen JP, Adams MJ: A black-streaked dwarf disease on rice in China is caused by a novel fijivirus. Arch Virol 2008, 153(10):1893-1898

2. Zhou GH, Wen JJ, Cai DJ, Li P, Xu DL, Zhang SG: Southern rice black-streaked dwarf virus: a new proposed Fijivirus species in the family Reoviridae. Chin Sci Bull 2008, 53:3677-3685 (in Chinese).

3. Hoang AT, Zhang HM, Yang J, Chen JP, Hébrard E, Zhou GH, Vinh VN, Cheng JA: Identification, characterization, and distribution of Southern rice black streaked dwarf virus in Vietnam. Plant Dis 2011, 95(9):1063-1069.

4. Zhai BP, Zhou GH, Tao XR, Chen X, Shen HM: Macroscopic patterns and microscopic mechanisms of the outbreak of rice planthoppers and epidemic SRBSDV. Chin J Appl Entomol 2011, 48(3):480-487 (in Chinese).

5. Matsukura K, Towata T, Sakai J, Onuki M, Okuda M, Matsumura M: Dynamics of southern rice black-streaked dwarf virus in rice and implication for virus acquisition. Phytopath 2013, 103:509-512.

6. Zhou GH, Zhang SG, Zou SF, Xu ZW, Zhou ZQ: Occurrence and damage analysis of a new rice dwarf disease caused by Southern rice black streaked dwarf virus. Plant Prot 2010, 36:144-146 (in Chinese).

7. Zhou GH, Xu DL, Xu DG, Zhang MX: Southern rice black-streaked dwarf virus: a white-backed planthopper transmitted Fiji virus threatening rice production in Asia. Front Microbiol 2013. doi:10.3389/fmicb.2013.00270.

8. Pu LL, Xie GH, Ji CY, Ling B, Zhang MX, Xu DL, Zhou GH: Transmission characters of Southern rice black streaked dwarf virus by rice planthoppers. Crop Prot 2012, 41:71-76.

9. Tu Z, Ling B, Xu DL, Zhang MX, Zhou GH: Effects of southern rice black-streaked dwarf virus on the development and fecundity of its vector, Sogatella furcifera. Virol J 2013, 10:145. doi:10.1186/1743-422X-10-145.

10. Wang H, Xu DL, Pu LL, Zhou GH: Southern rice black-streaked dwarf virus alters insect vectors' host orientation preferences to enhance spread and increase rice ragged stunt virus co-infection. Phytopathol 2014, 104:196-201.

11. Jiu M, Zhou XP, Tong L, Xu J, Yang X, Wan FH, Liu SS: Vector-virus mutualism accelerates population increase of an invasive whitefly. Plos One 2007, 2:e182. doi:10.1371/journal.pone.0000182.

12. Mouttet R, Bearez P, Thomas C, Desneux N: Phytophagous arthropods and a pathogen sharing a host plant: evidence for indirect plant-mediated interactions. Plos One 2011, 6:e18840.
13. Jeger MJ, van den Bosch F, Madden LV, Holt J: A model for analyzing plant-virus transmission characteristics and epidemic development. IMA J Math Appl Med Biol 1998, 15:1-18.

14. Jeger MJ, Holt J, van den Bosch F, Madden LV: Epidemiology of insect-transmitted plant viruses: modeling disease dynamics and control interventions. Physiol Entomol 2004, 29:291-304.

15. Pinner MS, Medina V, Plaskitt KA, Markham PG: Viral inclusion in monocotyledons infected by maize streak and related geminiviruses. Plant Patholy 1993, 42(1):75-87.

16. Stafford CA, Walker GP, Creamer R: Stylet penetration behavior resulting in inoculation of beet severe curly top virus by beet leafhopper, Circulifer tenellus. Entomol Exp Appl 2009, 130:130-137.

17. Xu Y, Zhou WW, Zhou YJ, Wu JX, Zhou XP: Transcriptome and comparative gene expression analysis of Sogatella furcifera (Horváth) in response to southern rice black-streaked dwarf virus infection. PLoS One 2012, 7(4):e36238.

18. Cao Y, Pan F, Zhou Q, Li GH, Liu SQ, Huang ZN, Li YZ: Transmission characteristics of Sogatella furcifera: a vector of the Southern rice blackstreaked dwarf virus. Chin J Appl Entomol 2011, 48:1314-1320.

19. Zhang J, Qin XW, Zheng X, Dong JH, Zhang ZK: Effects of SRBSDV-infected rice on the accumulation of energy substances of the virus vector, Sogatella furcifera (Horvath). J Environ Entomol 2013, 35(5):597-602 (in Chinese).

20. Jiménez-Martínez ES, Bosque-Perez NA, Berger PH, Zemetra RS: Life history of the bird cherry-oat aphid, Rhopalosiphum padi (Homoptera: Aphididae), on transgenic and untransformed wheat challenged with Barley yellow dwarf virus. J Econ Entomol 2004, 97(2):203-212.

21. Sinisterra XH, McKenzie CL, Hunter WB, Powell CA, Shatters RG Jr: Differential transcriptional activity of plant-pathogenic begomoviruses in their whitefly vector (Bemibia tabaci, Gennadius: Hemiptera, Aleyyrodidae). J Gen Virol 2005, 86(5):1525-1532.

22. Rubinstein $\mathrm{G}$, Czosnek $\mathrm{H}$ : Long-term association of tomato yellow leafcurl virus with its whitefly vector Bemisia tabaci: effect on the insect Uansmission capacity, longevity and fecundity. J Gen Virol 1997, 78(10):2683-2689.

23. Ogada PA, Maiss E, Poehling HM: Influence of tomato spotted wilt virus on performance and behaviour of western flower thrips (Frankliniella occidentalis). J Appl Entomol 2012, 27:1-10.

24. Zhou YJ: Rice Striped Virus Disease. Nanjing: Jiangsu Scientific and Technical Press; 2009:57-59.

25. Liang L, Guo JY, Tian JC, Chen Y, Hu C, Ye GY: Effects of rice dwarf virus on ovarian development and fecundity of the green leafhopper, Nephotettix cincticeps (Fabricius). Acta Phytophy Sin 2010, 4:375-376 (in Chinese).

26. Zhang T, Luan JB, Qi JF, Li M, Huang CJ, Zhou XP, Liu SS: Begomovirus-whitefly mutualism is achieved through repression of plant defenses by a virus pathogenicity factor. Mol Ecol 2012, 21(5):1294-1304

27. Li YZ, Cao Y, Zhou Q, Guo HM, Ou GC: The efficiency of southern rice black-streaked dwarf virus transmission by the vector Sogatella furcifera to different host plant species. J Integr Agri 2012, 11(4):621-627.

28. He XC, Xu HX, Zheng XS, Yang YJ, Gao GC, Pan JH, Lu Q, Lu ZX: Effects of rice black streaked dwarf virus on ecological fitness of non-vector planthopper. Rice Sci 2011, 19(4):335-338.

29. He YP, Zhang JF, Chen JM, Wu QC, Chen L, Chen LZ, Xiao PF, Zhu YC: Influence of pymetrozine on feeding behaviors of three rice planthoppers and a rice leafhopper using electrical penetration graphs. Ecotoxicol 2011, 104(6):1877-1884

30. Seo BY, Kwon YH, Jung JK, Kim GH: Electrical penetration graphic waveforms in relation to the actual positions of the stylet tips of Nilaparvata lugens in rice tissue. J Asia-Pac Entomol 2009, 12(2):89-95.

31. Sarria E, Cid M, Garzo E, Fereres A: Excel Workbook for automatic parameter calculation of EPG data. Comput Electron Agri 2009, 67:35-42.

\section{doi:10.1186/1743-422X-11-55}

Cite this article as: $X u$ et al: Southern rice black-streaked dwarf virus (SRBSDV) directly affects the feeding and reproduction behavior of its vector, Sogatella furcifera (Horváth) (Hemiptera: Delphacidae). Virology Journal 2014 11:55. 